\title{
Identifying the relationships of climate and physiological responses of a beech forest using the Standardised Precipitation Index: a case study for Slovakia
}

\author{
Jaroslav Vido ${ }^{1 *}$, Katarína Střelcová ${ }^{1}$, Paulína Nalevanková ${ }^{1}$, Adriana Leštianska ${ }^{1}$, Radoslav Kandrík ${ }^{1}$, \\ Alena Pástorová ${ }^{1}$, Jaroslav Škvarenina ${ }^{1}$, Tsegaye Tadesse ${ }^{2}$ \\ ${ }^{1}$ Department of Natural Environment, Faculty of Forestry, Technical University in Zvolen, T. G. Masaryka 24,96053 Zvolen, Slovakia.
2 The National Drought Mitigation Center, University of Nebraska-Lincoln, 816 Hardin Hall, 3310 Holdrege 8 Street, Lincoln, Nebraska.
${ }^{*}$ Corresponding author. E-mail: vido@tuzvo.sk
}

Abstract: The paper presents relationship between the Standardised Precipitation Index (SPI) and physiological responses of individual trees in a beech stand using an example of an experimental plot in Bienska valley (Zvolen, Slovakia). SPI is a widely used tool for monitoring both short-term and long-term droughts, and for the assessments of drought impacts on agriculture. Due to the complex ecosystem bonds, monitoring of drought in forests often requires a sophisticated technological approach. The aim of the paper was to correlate the SPI on the physiological responses of trees that were recorded during the performed physiological research (sap flow, and stem circumference increment) at the site in the growing seasons (May to September) of the years 2012-2014. The results revealed a relationship between the index and the physiological responses, although the problem with the impact of other environmental factors has also come up. The secondary correlation, in which soil water potential that significantly affects physiological responses of forest tree species was used as a dependent variable, showed a tighter relationship with the SPI. We found the highest correlation between the soil water potential and the values of SPI aggregated for five weeks. This indicates that the beech forest has a five week resistance to drought stress. The results also enable simple monitoring of the initiation of the drought stress by applying SPI for five weeks.

Keywords: Drought; Physiological responses; Beech; Standardised Precipitation Index; Soil water potential.

\section{INTRODUCTION}

Due to the ongoing non-specific and often unforeseeable changes in the climate system of the Earth, drought as a dangerous hydro-meteorological phenomenon, is increasingly becoming in the centre of the scientific interest, and also of the business, political, and public awareness (Botterill and Hayes, 2012; Lichner et al., 2014; Olesen et al., 2011). This is due to a wide range of severe impacts of drought on agricultural sector, water management, and dependent industries. Sivakumar et al. (2005) present that from the point of the impact risks, drought is the second most dangerous from the natural hazards at a global scale. Several historical records (Büntgen et al., 2007, 2010) have also confirmed that drought is an extremely dangerous phenomenon in the Central European region.

Despite the fact that the greatest damages caused by drought occur mainly in the agricultural sector (Eitzinger et al., 2013; Trnka et al., 2014), forestry has also been significantly affected (Charru et al., 2010; Hlásny et al., 2014). In forest ecosystems, drought causes direct losses in wood production, affects the utilisation of non-productive forest functions, disrupts ecological bonds and trophic structures, increases the risk of forest fires, and acts as a significant predisposing factor of the stand attack by harmful insects and pathogens (Allen et al., 2010; Granier et al., 2007; Zhang et al., 2013). Furthermore, largescale forest coverage changes have significant impacts on hydrological cycle although they may not be easy to identify by runoff indices (e.g., Holko et al., 2011). Early warning against these risks in forest ecosystems remains a challenge. In contrast to agricultural crops, which most frequently follow an annual production cycle with relatively controllable energy and material flows, long-lasting forest ecosystems are more structured and less controllable. Monitoring and prediction of drought in forest is more complex and often requires sophisticated tech- nical solution and simultaneously there is a number of key information gaps and scientific uncertainties (Allen et al., 2010). Due to this, the operative monitoring used in systems of early warning becomes limited. Considering the abovementioned facts, our attempt in the presented paper was to correlate the Standardised Precipitation Index (SPI) with selected physiological responses of forest ecosystems under drought stress conditions using a trial beech stand situated in Bienska valley (Central Slovakia). The aim of the paper is to outline the possibilities of using the Standardised Precipitation Index for drought monitoring in forests. Sap flow and transpiration as key indicators reflecting tree water status, play a major role in the research of drought impact on plants. At the same time, soil water availability and weather conditions were repeatedly identified as essential for tree growth and seasonal differences in stem circumferences (Chirino et al., 2011; Ježík et al., 2011; Konôpka et al., 2014).

\section{MATERIAL AND METHODS Area specification}

The correlation of the Standardised Precipitation Index with physiological responses of tree species was performed using the data from the research plot in Bienska valley (Zvolen, Slovakia) representing the years 2012-2014. The examined tree species was European beech (Fagus sylvatica L.). The experiment was carried out on individual trees in the mature 65-year-old stand situated at an elevation of $450 \mathrm{~m}$ above sea level. Geological substrate of the study area is composed mainly of volcanic parent material (andesite and andesitic tuffs). Soil at the research plot is classified as Haplic Cambisol (Humic, Eutric, Endoskeletic, Siltic). The textural class of the fine earth fraction is qualified as silt loam in the topsoil (upper 30-35 cm) or loam in the subsoil. Only few coarse rock fragments are in the upper 
horizons, but abundant coarse gravel and stones are present in the subsoil (70-80\% in C horizon). Higher content of coarse fragments is in the lower part of the research plot. The abundance of roots in the upper $35-40 \mathrm{~cm}$ of soil is relatively high. Only very few roots are present deeper in $\mathrm{B} / \mathrm{C}$ and $\mathrm{C}$ horizons (Sitková et al., 2014).

\section{Measured physiological and soil moisture characteristics}

From the physiological characteristics, sap flow and stem circumference increment of six sample trees (with average diameter $32 \mathrm{~cm}$ and $25.4 \mathrm{~m}$ ) were assessed. These characteristics were measured using automatic instruments produced by the company of EMS Brno, CZ: SapFlow system EMS51A based on trunk heat balance method (Čermák et al., 2004) and Dendrometer DRL26. One set of sap flow system and one band dendrometer were installed on each tree trunk. The dendrometer was mounted at height $2.5 \mathrm{~m}$.

Sap flow values were measured in liters per hour per centimeter of stem circumference $\left(\mathrm{L} \cdot \mathrm{h}^{-1} \cdot \mathrm{cm}^{-1}\right)$. The values for the whole stem of each tree were obtained multiplying by circumference $\left(L . h^{-1}\right)$. Average values of sap flow were calculated as the arithmetic mean of sample trees. We evaluated only the growing seasons (May to September) of the above-mentioned years.

As a derived characteristic of drought, soil water potential (SWP) was also measured at the research plot. This characteristic was measured by standard measuring equipment using gypsum blocks (Delmhorst Inc., USA) and MicroLog SP3 datalogger (EMS Brno, CZ). Three soil water potential probes were deployed. Each probe conducted measurement at three soil depths $(15,30$ and $50 \mathrm{~cm})$. SWP values used in this study were calculated as mean value of the SWP from the above mentioned soil depths.

\section{Meteorological data}

Meteorological data were obtained from two sources. The first source were the measurements from the automatic meteorological station located directly at the research plot (period 2012-2014). To derive the Standardised Precipitation Index (described in following section), long-term data series (period 1961-2014) from a nearby meteorological station of the Slovak Hydro-meteorological Institute (SHMI) situated in Sliač was used. Meteorological station Sliač is located approximately 6.2 $\mathrm{km}$ northeast of the research plot. The station altitude is 313 meters above sea level. The comparability of the meteorological data from these two stations was confirmed with the test of equality of averages for the precipitation total. The test showed high compliance rate at a significance level of $\alpha=0.05$.

\section{Standardised Precipitation Index}

In order to fulfil the objective of the paper, the Standardised Precipitation Index (SPI) was used (McKee et al., 1995). The SPI is based on precipitation data and has the flexibility to detect both short- and long-term precipitation deficits. According to the methodology of McKee et al. (1995), the unique feature of the SPI is that the index can be used to monitor conditions on a variety of time scales. Due to this, it is possible to evaluate diverse impacts of drought from agricultural to hydrological sectors (Hayes et al., 1999; Wilhelmi et al., 2008; Wilhite and Glanz, 1985). To compute SPI long-term precipitation data series are fitted to a gamma probability distribution function as follows:

$$
\begin{aligned}
& g(x)=\frac{1}{\beta^{\alpha} \Gamma(\alpha)} x^{\alpha-1} e^{-x / \beta} \\
& \Gamma(\alpha)=\sum_{0}^{\infty} x^{\alpha-1} e^{-x} d x
\end{aligned}
$$

where $x$ is precipitation amount in ( $\mathrm{mm})$ at a certain time scale, $\alpha$ represents a shape parameter, $\beta$ is a scale parameter and $\Gamma(\alpha)$ defines a gamma function. The distribution function, from which probabilities can be obtained, is:

$$
G(x)=\int_{0}^{x} g(t) d t
$$

However, because the gamma function is undefined for $\mathrm{x}=$ 0 , cumulative probability $H(\mathrm{x})$ is calculated as follows:

$$
H(x)=q+(1-q) G(x)
$$

where $q$ is the probability of a zero, and is estimated by $\frac{m}{n}$, in which $m$ is the number of zeros in precipitation time series $n$.

Finally, the cumulative probability $H(x)$ is converted to the standard normal variable $(Z)$ or the $S P I$ value using an approximation provided by Abramowitz and Stegun (1965):

$$
\begin{aligned}
& Z=S P I=-\left(t-\frac{c_{0}+c_{1} t+c_{2} t^{2}}{1+d_{1} t+d_{2} t^{2}+d_{3} t^{3}}\right) \text { for } 0<H(x) \leq 0.5 \\
& Z=S P I=+\left(t-\frac{c_{0}+c_{1} t+c_{2} t^{2}}{1+d_{1} t+d_{2} t^{2}+d_{3} t^{3}}\right) \text { for } 0.5<H(x)<1.0
\end{aligned}
$$

where:

$$
\begin{aligned}
& t=\sqrt{\ln \left(\frac{1}{(H(x))^{2}}\right)} \text { for } 0<H(x) \leq 0.5 \\
& t=\sqrt{\ln \left(\frac{1}{(1.0-H(x))^{2}}\right)} \text { for } 0.5<H(x)<1.0
\end{aligned}
$$

$$
\begin{aligned}
& c_{0}=2.515517 \\
& c_{1}=0.802853 \\
& c_{2}=0.010328 \\
& d_{1}=1.432788 \\
& d_{2}=0.189269 \\
& d_{3}=0.001308
\end{aligned}
$$

So the SPI represents a z-score, or the number of standard deviations above or below that an event is from the mean. In other words, the SPI represents a cumulative probability (for specified time scale) in relation to the base period for which the gamma parameters were estimated. In Table 1 are described values of the SPI with corresponding cumulative probability and with appropriate classification of the severity by McKee et al. (1995). The SPI has been applied in a number of international works dealing with the research of drought impacts on ecological environmental conditions (Kim et al., 2014; Moreira et al., 2008; Nam et al., 2015). 
Table 1. Categories of the SPI based on the SPI value.

\begin{tabular}{l|l|l}
\hline SPI values & Category & Cumulative probability \\
\hline$\geq 2$ & Extremely wet & $\geq 0.9772$ \\
1.5 to 1.99 & Severely wet & 0.9332 to 0.9772 \\
1.0 to 1.49 & Moderately wet & 0.8413 to 0.9332 \\
-0.99 to 0.99 & Near normal & 0.1587 to 0.8413 \\
-1.49 to -1.0 & Moderately dry & 0.0668 to 0.1587 \\
-1.99 to -1.5 & Severely dry & 0.0228 to 0.0668 \\
$\leq-2$ & Extremely dry & $\leq 0.0228$ \\
\hline
\end{tabular}

\section{Correlation between the SPI and physiological characteristics}

The correlation of the Standardised Precipitation Index with physiological responses was performed using the method of correlation analysis by searching for the highest correlation rates between the values of the SPI (on various time scales) and physiological responses (stem circumference increment, sap flow, and soil water potential - as a derived drought characteristic). The initial time step in the correlation analysis was one month. Further, we analysed also two- and three- month SPI. However, correlation rates varied between 0.1 (for one month SPI) to 0.05 (for three- month SPI) by stem circumference increment and 0.01 (for one month SPI) to 0.06 (for threemonth SPI) by sap flow respectively. Because of the low correlations we determined that it is necessary to work with a weekly time-step. Therefore, the process of increasing correlation then continued using SPI with a weekly time-step (SPI W). In the case of physiological characteristics, we evaluated a weekly total. These values were correlated with SPI W for the same week, however on specific time scale. By relationship between SPI W and soil water potential, the average daily value of the soil water potential of the last day in evaluated time step of the SPI were used. The highest possible level of correlation and statistical significance between the variables was obtained by the gradual extension of the time scale. Particularly time scale (aggregations) of SPI W for: 1, 2, 3, 4, 5, 6, 7 and 8 weeks were evaluated.

Because weekly time-step of the Standardised Precipitation Index (SPI W) was applied, further analyses on normality of the SPI W were conducted using Shapiro-Wilk test. Wu et al. (2007) described the problem by drought analyses using shortterm (weekly time-step) SPI. Because of the SPI specific calculation, weekly time-step could be problematic in low precipitation situations. In these cases, the SPI tend to over-estimate low precipitation. From the mathematical point of view, the SPI values are lower bounded when a high frequency of zero values (no precipitation cases) occurs, what leads to a non-normally distributed SPI. We tested only SPI W for four and five weeks (for each week in growing season), because the best correlations were found on this time scales, as described in results. We found that the SPI W aggregated for 4 weeks is non-normally distributed in the $25^{\text {th }}$ and $27^{\text {th }}$ week of year and SPI W aggregated for 5 weeks has this problem in the $26^{\text {th }}$ and $27^{\text {th }}$ week of year (Fig. 1). Because this could lead in to the bias in correlation analyses, these weeks (time-steps) were not used.

\section{RESULTS AND DISCUSSION \\ Climatological characteristics of the vegetation seasons 2012-2014}

All months of the vegetation seasons were characterised by mean air temperature above long-term mean 1961-1990 (normal), except August 2014. Mean monthly temperature of this month was $0.2^{\circ} \mathrm{C}$ below normal. The warmest vegetation season was 2012. Deviation of mean air temperature of this vegetation period ranged from $+2.4^{\circ} \mathrm{C}$ in May to $+3.4^{\circ} \mathrm{C}$ in August compared to normal. On the contrary the coldest vegetation season was 2014. Deviation of mean air temperature ranged from $-0.2^{\circ} \mathrm{C}$ in August to $+1.8^{\circ} \mathrm{C}$ in July compared to normal. Despite this, the mean air temperature of this vegetation season was $0.9^{\circ} \mathrm{C}$ higher than normal. Driest vegetation season was 2012 with precipitation total of $283 \mathrm{~mm}$ (from May to September) compared to precipitation normal of $350 \mathrm{~mm}$. Vegetation season of 2014 was unusually wet $(534 \mathrm{~mm})$. Climatological characteristics of the vegetation seasons 2012-2014 are described in Fig. 2.

\section{Sap flow in relation to SPI}

Sap flow is highly related to transpiration which is one of the fundamental physiological expressions of plants. The impact of drought on plant transpiration is an up-to-date question (Betsch et al., 2011; Huang et al., 2009; Klein et al., 2014), but the attempt to examine the correlations between transpiration rate of tree species and drought indices is relatively novel. Due to the high level of resistance and resilience of tree species against drought (with regard to the physiognomy of tree species starting from "water management" up to the depth of the rooting system), the expected effect of soil water shortage became evident only after several consecutive weeks characterised by the continuous meteorological drought. By gradual testing of correlations we reached the maximum level of $\mathrm{R}^{2}=0.082$ for a three-week SPI (W3) at a significance level $\alpha=0.05$. Despite the significant impact of precipitation on sap flow, the small value of the correlation indicates that there are other

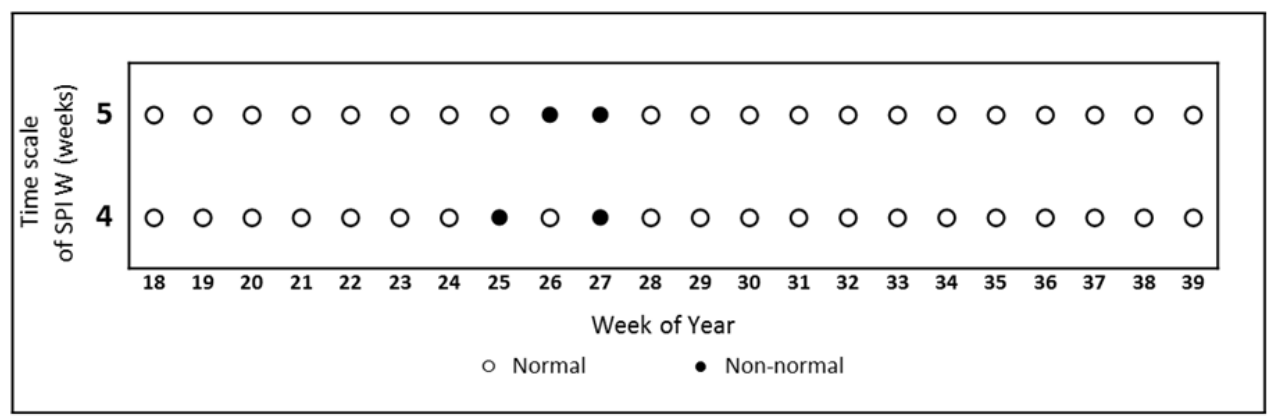

Fig. 1. SPI non-normality distribution plots. The $x$-axis depicts the week of the year. The y-axis shows the weekly time scale of the SPI. White circles represent weeks with normally distributed SPI and black circles denote non-normal distribution. 


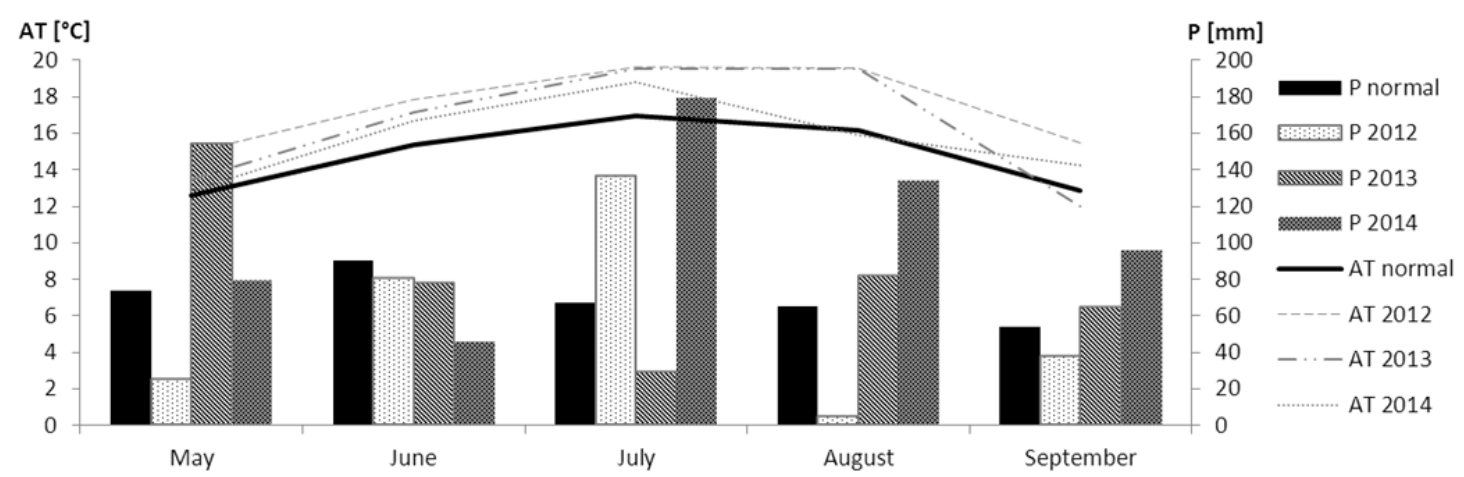

Fig. 2. Monthly means of air temperature (AT) and precipitation totals (P) in vegetation seasons 2012-2014 compare to the long-term mean (normal) of 1961-1990.

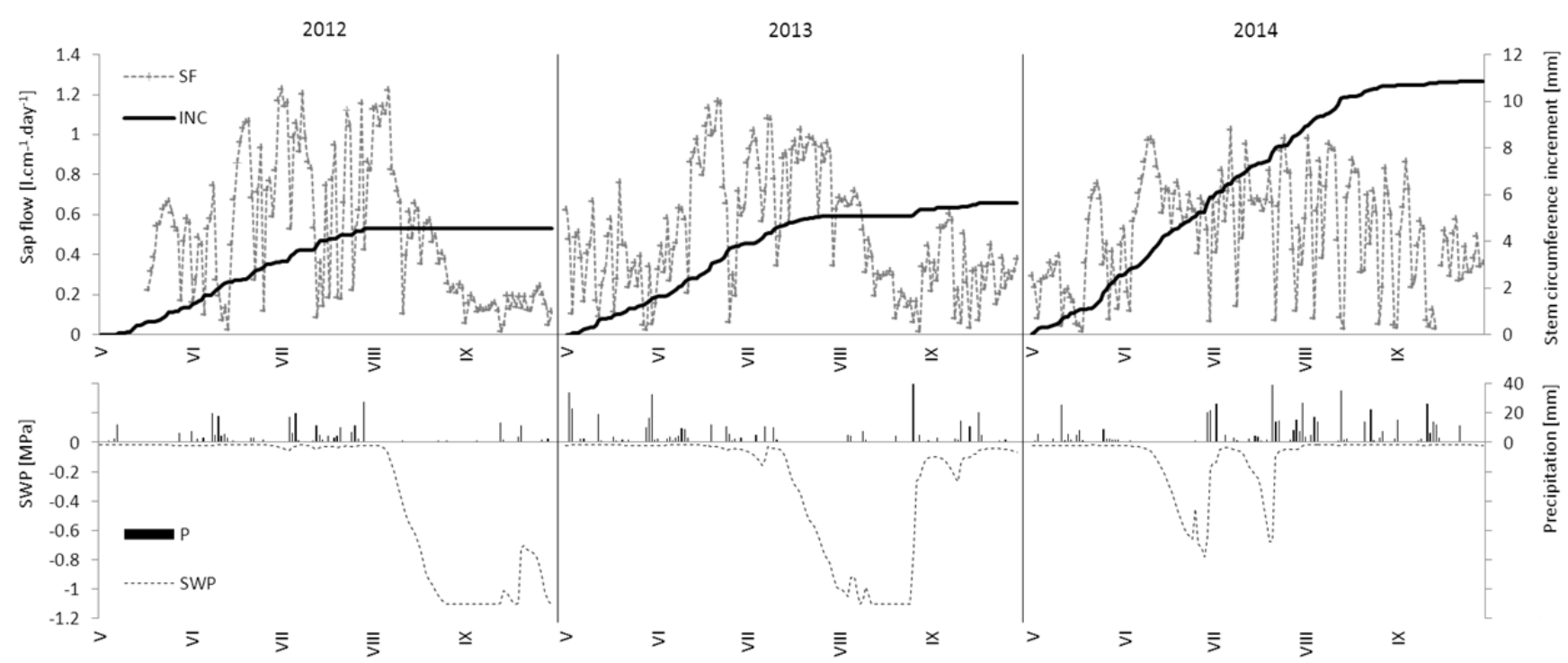

Fig. 3. Seasonal course of daily sap flow variations (SF), cumulative circumference increment (INC) and soil water potential (SWP) in respect to precipitation (P) during vegetation seasons of 2012-2014.

environmental variables affecting the level of sap flow. This statement seems to be contradicting, since soil water deficit (as a result of the lack of precipitation) is a limiting factor for transpiration (Kučera et al. 2011; Matejka et al. 2009; Tesař et al. 2006, 2007). However these authors state that in situations with sufficient water supply the transpiration is driven by evaporative demand of atmosphere (vapour pressure deficit) and global radiation. Thus low transpiration rates occur also in rainy periods (situations with sufficient soil water supply). It is because of high water vapour pressure (low vapour pressure deficit) and low intensity of global radiation during rainy weather. This is confirmed also in Fig. 3. This could be the reason of low correlation of SPI and sap flow. Based on this result we can conclude that it is not possible to estimate the limitations of sap flow rate of beech from SPI. In other words, the SPI is not a good indicator of sap flow rate. This, however, does not say anything about the impact of the drought on transpiration.

\section{Stem circumference increment in relation to SPI}

Stem increment is a production characteristic that is extremely important in relation to drought. Examining the correlations between one-week-long circumference increments and SPI is therefore scientifically and practically interesting. The highest correlation between increments and SPI values was found for SPI W (week step of SPI) for four weeks. The correlation coefficient $\left(\mathrm{R}^{2}=0.2169(\alpha=0.05)\right.$ (Fig. 4) indicates a closer relationship compared to sap flow $\left(\mathrm{R}^{2}=0.082(\alpha=0.05)\right.$, although the correlation coefficient is still small.

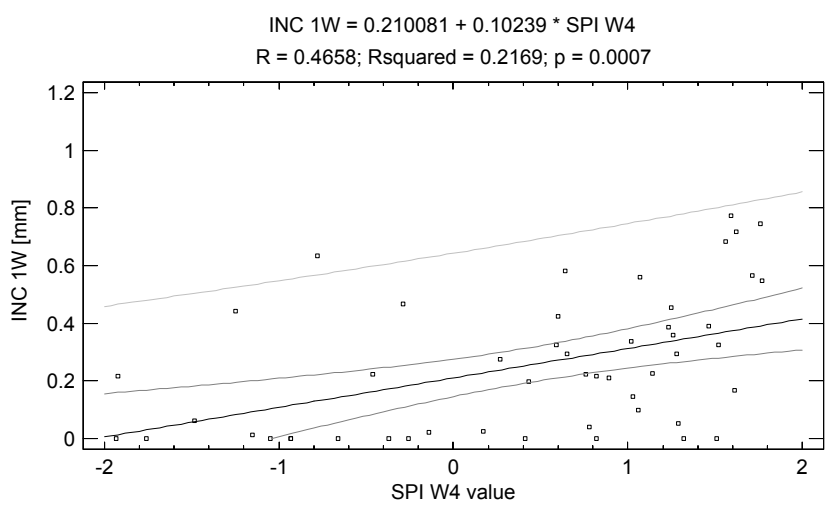

Fig. 4. Correlation between Standardised Precipitation Index aggregated for four weeks (SPI W4) and one-week circumference increment (INC 1W). 
It is therefore evident that the increment as an ecological and production characteristic is more sensitive to drought stress represented by the SPI. The attempts to increase correlations by changing the time step of SPI W led to lower correlation rates. The results confirm that the increment of tree species is not only the function of precipitation, but similarly to transpiration it is a phenomenon affected by multiple factors. However, it is evident that the circumference increment was significantly lower in the driest vegetation period 2012 than in the wet vegetation season of 2014 (Fig. 3). With a certain level of caution, the results indicate that the drought begins to have an impact on beech increment after four consecutive weeks with a continuous lack of precipitation.

\section{Soil water potential in relation to SPI}

Considering the above-mentioned loose relationships between the SPI and physiological characteristics, we decided to perform a secondary parametrisation in the form of assessing the impact of the Standardised Precipitation Index on soil water potential. This solution is based upon the published results (Ježík et al., 2015; Sitková et al., 2014) that confirmed the significant impact of soil water potential (which in the figurative sense means drought) on physiological responses of tree species, in our case European beech. The search for the highest correlation followed the methodological procedure presented above. The highest correlation was found between the weekly average values of soil water potential and SPI W for five weeks (Fig. 5).

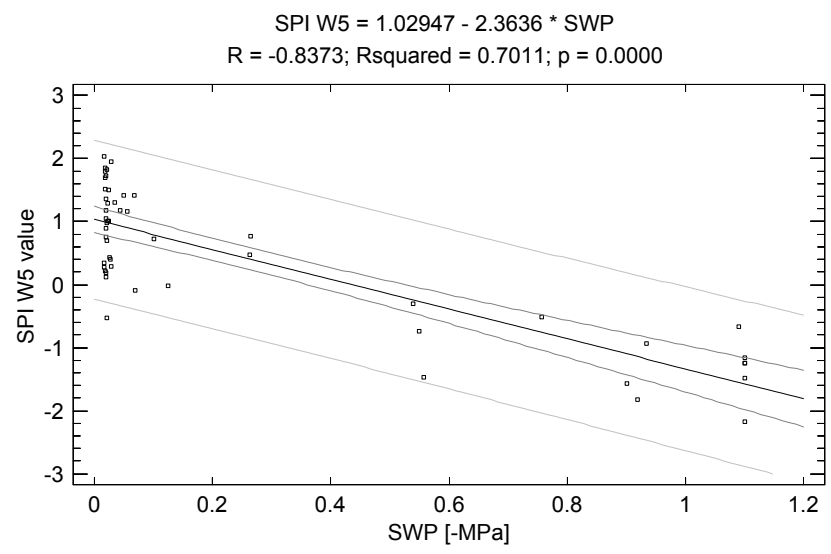

Fig. 5. Correlation between soil water potential (SWP) and Standardised Precipitation Index for five weeks (SPI W5).

This relationship was significant at $\alpha=0.05, \mathrm{R}^{2}=0.7011$, which indicates close relationship between soil water potential and SPI. The correlation of index and soil water potential showed that the value of soil water potential decreases after five consecutive weeks with continuous meteorological drought. The result of the secondary correlation can be considered as a threshold for the start of the drought stress in a stand typical of site at Bienska valley, which represents forest ecosystems of the Slovak Republic, situated at mid-elevations. Hence, we conclude that a value of SPI W aggregated for five weeks can be used to determine the beginning of the drought in beech forests situated at mid-elevations in Slovakia. This simple method could be used to identify the beginning of the drought stress in beech forests using the meteorological index of SPI.

\section{CONCLUSIONS}

The paper deals with the relationship of SPI with physiological responses of tree species at the forested site of Bienska valley (Zvolen, Slovakia). We found that the secondary parameterisation of the Standardised Precipitation Index on soil water potential (as a driver of plant physiological responses) led to relatively conclusive results. These can be summarised as follows: the studied forest ecosystem response to drought began to be evident after five consecutive weeks of the continuous meteorological drought expressed by the SPI for five weeks (SPI W5). This temporal resistance has been also confirmed by assessing of stem increment. It indicates the resistance of an ecosystem for five weeks after which the first symptoms of drought in beech forests become evident. This allows us to apply the outcomes for monitoring the beginning of drought in beech forests using a simple SPI drought index and check if this simple method provides reasonable results also in other study areas. Direct impact of the drought on physiological responses of beech, i.e. the dominant species of forest ecosystems at midelevations, was partially confirmed by stem circumference increment.

Acknowledgement. This work was supported by the Slovak Research and Development Agency on the base of the contracts No. APVV-0111-10, APVV-0480-12 and VEGA 1/0589/15, VEGA 2/0101/14, VEGA 1/0367/16.

\section{REFERENCES}

Abramowitz, M., Stegun, I.A., 1965. Handbook of Mathematical Functions with Formulas, Graphs and Mathematical Tables. Dover Publications, Inc., New York, 1046 p.

Allen, C.D., Macalady, A.K., Chenchouni, H., Bachelet, D., Mcdowell, N., Vennetier, M. et al., 2010. A global overview of drought and heat-induced tree mortality reveals emerging climate change risks for forests. Forest Ecol. Manag., 259, 4, 660-684.

Betsch, P., Bonal, D., Breda, N., Montpied, P., Peiffer, M., Tuzet, A., Granier, A., 2011. Drought effects on water relations in beech: The contribution of exchangeable water reservoirs. Agr. Forest Meteorol., 151, 5, 531-543.

Botterill, L.C., Hayes, M.J., 2012. Drought triggers and declarations: science and policy considerations for drought risk management. Nat. Hazards, 64, 1, 139-151.

Büntgen, U., Frank, D.C., Kaczka, R.J., Verstege, A., ZwijaczKozica, T., Esper, J., 2007. Growth responses to climate in a multi-species tree-ring network in the Western Carpathian Tatra Mountains, Poland and Slovakia. Tree Physiol., 27, 5, 689-702.

Büntgen, U., Brázdil, R., Frank, D., Esper, J., 2010. Three centuries of Slovakian drought dynamics. Clim. Dynam., 35, 2-3, 315-329.

Čermák, J., Kučera, J., Nadezhdina, N., 2004. Sap flow measurements with some thermodynamic methods, flow integration within trees and scaling up from sample trees to entire forest stands. Trees, 18, 529-546.

Eitzinger, J., Trnka, M., Semerádová, D., Thaler, S., Svobodová, E., Hlavinka, P., Šiška, B., Takáč, J., Malatinská, L., Nováková, M., Dubrovský, M., Žalud, Z., 2013. Regional climate change impacts on agricultural crop production in Central and Eastern Europe-hotspots, regional differences and common trends. J. Agr. Sci.-Cambridge, 151, 6, 787-812.

Granier, A., Reichstein, M., Bréda, N., Janssens, I.A., Falge, E., Ciais, P., Grünwald, T., Aubinet, M., Berbigier, P., Bernhof- 
er, C., Buchmann, N. et al., 2007. Evidence for soil water control on carbon and water dynamics in European forests during the extremely dry year: 2003. Agr. Forest Meteorol., 143, 123-145.

Hayes, M.J., Svoboda, M.D., Wilhite, D.A., Vanyarkho, O.V., 1999. Monitoring the 1996 drought using the standardized precipitation index. Bull. Am. Meteorol. Soc., 80, 3, 429438.

Hlásny, T., Mátyás, C., Seidl, R., Kulla, L., Merganičová, K., Trombik, J., Dobor, L., Barcza, Z., Konôpka, B., 2014. Climate change increases the drought risk in Central European forests: What are the options for adaptation? Forestry Journal, 60, 1, 5-18.

Holko, L., Parajka, J., Kostka, Z., Škoda, P., Blöschl, G., 2011. Flashiness of mountain streams in Slovakia and Austria. J. Hydrol., 405, 392-401.

Huang, Y., Zhao, P., Zhang, Z., Li, X., He, Ch., Zhang, R., 2009. Transpiration of Cyclobalanopsis glauca (Quercus glauca) stand measured by sap-flow method in a karst rocky terrain during dry season. Ecol. Res., 24, 4, 791.

Charru, M., Seynave, I., Morneau, F., Bontemps, J.D., 2010. Recent changes in forest productivity: An analysis of national forest inventory data for common beech (Fagus sylvatica L.) in north-eastern France. Forest Ecol. Manag., 260, 5, 864-874.

Chirino, E., Bellot, J., Sanchéz, J.R., 2011. Daily sap flow rate as an indicator of drought avoidance mechanisms in five Mediterranean perennial species in semi-arid southeastern Spain. Trees, 25, 4, 593-606.

Ježík, M., Blaženec, M., Střelcová, K., Ditmarová, L., 2011. The impact of the $2003-2008$ weather variability on intraannual stem diameter changes of beech trees at a submontane site in Slovakia. Dendrochronologia, 29, 227-235.

Ježík, M., Blaženec, M., Letts, M.G., Ditmarová, L'., Sitková, Z., Střelcová, K., 2015. Assessing seasonal drought stress response in Norway spruce (Picea abies (L.) Karst.) by monitoring stem circumference and sap flow. Ecohydrol., 8, 3, 378-386.

Kim, C.J., Park, M.J., Lee, J.H., 2014. Analysis of climate change impacts on the spatial and frequency patterns of drought using a potential drought hazard mapping approach. Int. J. Climatol., 34, 1, 61-80.

Klein, T., Rotenberg, E., Cohen-Hilaleh, E., Raz-Yaseef, N., Tatarinov, F., Preisler, Y. et al., 2014. Quantifying transpirable soil water and its relations to tree water use dynamics in a water-limited pine forest. Ecohydrol., 7, 2, 409-419.

Konôpka, B., Pajtík, J., Bošel'a, M., Hlásny, T., Sitková, Z., 2014. Inter- and intra- annual dynamics of height increment in young beech and spruce stands in relation to tree size and weather conditions. Lesnícky časopis - Forestry Journal, 60, 51-59.

Kučera, J., Jimenéz, M.S., Morales, D., Urban, J., 2011. Transpirace a průduchová vodivost Pinus canariensis za kontrastních podmínek dostupnosti půdní vody. [Transpiration and stomatal conductance of Pinus canariensis under different soil water availability]. In: Střelcová, K., Sitková, Z., Kurjak, D., Kmet', J. (Eds.): Stres suchom a lesné porasty (Aktuálny stav a výsledky výskumu). [Drought stress and forests (Current status and research outcomes)]. Technical University in Zvolen, Zvolen, pp. 254-262. (In Slovak.)
Lichner, L., Cerdà, A., Tesař, M., Rajkai, K., 2014. Biohydrology research after Landau 2013 conference. J. Hydrol. Hydromech., 62, 4, 253-257.

Matejka, F., Střelcová, K., Hurtalová, T., Gömöryová, E., Ditmarová, L., 2009. Seasonal changes in transpiration and soil water content in a spruce primeval forest during a dry period. In: Střelcová, K. et al. (Eds.): Bioclimatology and natural hazards. Springer, $298 \mathrm{p}$.

McKee, T.B., Doesken, N.J.,J. Kleist, 1995. Drought monitoring with multiple time scales. In: Preprints $9^{\text {th }}$ Conference on Applied Climatology, January 15-20, Dallas, Texas, pp. 233-236.

Moreira, E.E., Coelho, C.A., Paulo, A.A., Pereira, L.S., Mexia, J.T., 2008. SPI-based drought category prediction using loglinear models. J. Hydrol., 354, 1, 116-130.

Nam, W.H., Hayes, M.J., Svoboda, M.D., Tadesse, T., Wilhite, D.A., 2015. Drought hazard assessment in the context of climate change for South Korea. Agr. Water Manage., 160, 106-117.

Olesen, J.E., Trnka, M., Kersebaum, K.C., Skjelvåg, A.O., Seguin, B., Peltonen-Sainio, P. et al., 2011. Impacts and adaptation of European crop production systems to climate change. Eur. J. Agron., 34, 2, 96-112.

Sitková, Z., Nalevanková, P., Střelcová, K., Fleischer, P.Jr., Ježík, M., Sitko, R., Pavlenda, P., 2014. How does soil water potential limit the seasonal dynamics of sap flow and circumference changes in European beech? Forestry Journal, $60,1,19-30$.

Sivakumar, M., Motha, R., Das, H., 2005. Natural Disasters and Extreme Events in Agriculture. Springer, Berlin, 376 p.

Tesař, M., Šír, M., Lichner, L', Zelenková, E., 2006. Influence of vegetation cover on thermal regime of mountainous catchments. Biologia, 61, Suppl. 19, S311-S314.

Tesař, M., Šír, M., Lichner, L., Čermák, J., 2007. Plant transpiration and net entropy exchange on the Earth's surface in a Czech watershed. Biologia, 62, 5, 547-551.

Trnka, M., Rötter, R.P., Ruiz-Ramos, M., Kersebaum, K.C., Olesen, J.E., Žalud, Z., Semenov, M.A., 2014. Adverse weather conditions for European wheat production will become more frequent with climate change. Nature Climate Change, 4, 7, 637-643.

Wilhelmi, O.V., Hayes, M.J., Thomas, D.S., 2008. Managing drought in mountain resort communities: Colorado's experiences. Disaster Prev. Manag., 17, 5, 672-680.

Wilhite, D.A., Glantz, M.H., 1985. Understanding the Drought Phenomenon: The Role of Definitions. Water Int., 10, 3, 111-120.

Wu, H., Svoboda, M.D., Hayes, M.J., Wilhite, A., Wen, F., 2007. Appropriate application of the Standardized Precipitation Index in arid locations and dry seasons. Int. J. Climatol., 27, 65-79.

Zhang, Y., Peng, C., Li, W., Fang, X., Zhang, T., Zhu, Q. et al., 2013. Monitoring and estimating drought-induced impacts on forest structure, growth, function, and ecosystem services using remote-sensing data: recent progress and future challenges. Environ. Rev., 21, 2, 103-115.

Received 25 September 2015 Accepted 22 February 2016 